\title{
James Ellroy's Critical Criminology: Crimes of the Powerful in the Underworld USA Trilogy
}

\author{
Rafe McGregor $^{1}$ (D) \\ Published online: 2 August 2019 \\ (c) The Author(s) 2019
}

\begin{abstract}
This article argues for the criminological value of James Ellroy's fiction, using his Underworld USA Trilogy (the "Trilogy") as a case study. I present the Trilogy as a critical criminological enterprise, understood in the sense of offering a convincing explanation of the cause(s) of social harm-specifically, those committed by various agencies of the American government from the late 1950s to the early 1970s. Ellroy's Trilogy provides this explanation in two distinct ways, using literary devices first to establish a counterfactual vision of America during the 1960s and then to represent the lived experience of perpetrators of state-sponsored social harm. In conveying such criminological knowledge, the Trilogy constitutes an instance of critical criminology and demonstrates the exercise of the criminological imagination.
\end{abstract}

\section{Introduction: Narrative Criminology and Criminological Fiction}

Criminology has been slow to embrace narrative as a tool for understanding, explaining, and reducing crime and social harm. The narrative turn in criminology is a phenomenon of the new century, with four of the most influential books in the field published in little more than a decade: Shadd Maruna's (2001) Making Good: How Ex-Convicts Reform and Rebuild Their Lives; Lois Presser's (2008) Been a Heavy Life: Stories of Violent Men; Sveinung Sandberg and Willy Pedersen's (2009) Street Capital: Black Cannabis Dealers in a White Welfare State; and Presser's (2013) Why We Harm. The term, narrative criminology, was first coined by Presser (2009: 178), and Presser and Sandberg (2015) collaborated to edit Narrative Criminology: Understanding Stories of Crime, which is currently the definitive work on the narrative turn in criminology. Presser and Sandberg (2015: 1) define narrative criminology broadly, as any inquiry based on the view of stories as instigating, sustaining, or effecting desistance from harmful action."

Presser (2016) identifies her own approach-as well as that of Sandberg and Pedersen (2009) and Thomas Ugelvik (2014)_ as distinguishable from previous intersections of narrative representation and criminological inquiry in two ways. First, narrative criminology

Rafe McGregor

Mcgregor@edgehill.ac.uk

1 Department of Law and Criminology, Edge Hill University, St Helens Road, Ormskirk L39 4QP, UK 
focuses on the form of narratives rather than their content. Second, narrative criminology regards narratives as constitutive rather than representational insofar as it regards stories as shaping experience instead of providing evidence of events or evidence of the way in which events are, have been, or were experienced. Presser's (2009) core claim is that because experience is storied, internal narratives provide an understanding of criminal behavior by explaining future actions as either realizing or advancing individual or collective narratives of offenders.

Presser identifies two key intersections of narrative and criminology. The first assigns narrative a central role in theoretical criminology by means of a constitutive approach to narrative (Presser 2009). The second is the use of narrative as a method-as part of a methodological toolkit - and focuses on the composition of narratives, the assignment of characters, and the development of plotlines within individual and collective narratives (Presser 2016).

Sandberg (2010), Sandberg and Ugelvik (2016), and Presser and Sandberg (2019) all refer to narrative criminology as a framework, and this is the most useful way to conceive of this particular type of criminological inquiry, i.e., as a shared commitment about what research questions are important, what data are relevant, how that data should be interpreted, and what counts as a satisfying answer to those research questions. This shared commitment includes the story as one of the main explanatory variables in criminology, the relevance of stories to the causes of crime and social harm, and the significance of stories to desistance from crime and social harm. Thus far, work within the narrative criminological framework has focused on the life stories of offenders. As per the constitutive approach adopted by narrative criminologists, the question of whether these stories are "true" or "false" is irrelevant—what matters is the extent to which they determine the social reality of offenders and motivate either future harm or future desistance from harm.

The distinction between truth and falsity similarly fails to differentiate between nonfictional narratives and fictional narratives. First, there is a strong sense in which the structuring of a sequence of events into a recognizable narrative fictionalizes those events. For example, in Presser's (2008) initial study of twenty-seven violent men, all of the life stories narrated focused on either reform (character development over time), stability (personal integrity under duress), or a combination of the two. Even those stories that represented historical reality with complete accuracy had meaning appended retrospectively in order to narrate a story that was either about reform or about stability (or both). Second, there is also a strong sense in which there is truth in fiction. The relation between fictional people, places, events and the world is often understood in terms of reference to universals (McGregor 2016). This notion originates with Aristotle's (2004) famous observation on the superiority of poetry over history: the latter (history) refers to what has happened (particulars) and the former (poetry) to the kinds of thing that can happen (universals).

I take the most promising account of the distinction between non-fiction and fiction to be Peter Lamarque and Stein Haugom Olsen (1994) conception of fiction as a rule-bound practice that informs a particular type of communication between an author or director, on the one hand, and a reader or audience, on the other. To create a work of fiction in a verbal or visual tradition is to make a fictive utterance, and to experience that oeuvre as a piece of fiction is to adopt the fictive stance. The authorial or directorial invitation to experience a work as fiction is thus matched by a set of expectations in readers and audiences. The expectations associated with the practice of fiction differ from those associated with the practice of non-fiction. Typically, there is a desire for a closer correspondence between representation and reality, in the latter, and a greater tolerance for inventiveness, imaginativeness, and fabrication, in the former. 
Criminologists have, for the most part, approached explicitly fictional narratives from three distinct perspectives. In cultural criminology, the emphasis has been on fiction as a reflection of society or on the reciprocal relation between fiction and society (e.g., Cavender and Jurik 2012; Rafter 2006). Green cultural criminology has utilized the narrative criminological toolkit to emphasize inter alia fiction's potential to change social attitudes toward environmental crimes, harms and responses thereto (e.g., Brisman 2013, 2017, 2019a). For popular criminology, fiction is a pedagogical tool, illustrating and exemplifying criminological theories and concepts (e.g., Atherton 2013; Rafter and Brown 2011).

Thus far, there have been only three sustained arguments for the more extensive role for fiction intimated by green cultural criminology. Vincenzo Ruggiero (2003) has advanced fiction, in general, and literature, in particular, as providing a view of sociological and criminological reality that is mediated by value and imagination. Jon Frauley (2010) has drawn attention to the way in which fictional realities, whether literary or cinematic, can be used in the analysis and clarification of sociological and criminological ideas. In Narrative Justice (McGregor 2018), I exploited the distinction between documentary narratives and fictional narratives for the purpose of the disclosure and demystification of criminal inhumanity.

Of these three theories, Frauley's (2010) is the most useful for my purposes. He argues first for a greater recognition of the significance of theory and the practice of theorizing within criminology and then for the value of fictional realities for theory and theorizing. Frauley understands this value in terms of the criminological imagination, which draws on C. Wright Mills' (1959) concept of the sociological imagination. Mills (1959: 8) was concerned with, among other problems, the disconnect between "personal troubles" and "public issues" in both academic sociology and public policy in the mid-twentieth century. Frauley has been troubled by the same lacuna in criminology at the beginning of the twenty-first century and regards fictional realities as an analytic tool for the exercise of the criminological imagination. He (Frauley 2010: 21) proposes a "craft-enterprise model," in which the reflexive, rigorous, and systematic analysis of fictional realities is employed to provide empirical referents for theory, and he claims that the criminological imagination has at least three functions within the discipline: mapping relations between personal troubles and public issues; mapping the structure of social reality; and offering a conceptual system in which data can be interpreted. ${ }^{1}$

My argument is that James Ellroy exercises his own criminological imagination in the Underworld USA Trilogy (the "Trilogy") and that, as a result, the Trilogy constitutes a critical criminological enterprise. This argument is made within the narrative criminological framework, construed as my commitment to story as one of the main explanatory variables in criminology, the relevance of stories to the causes of crime and social harm, and the significance of stories to desistance from crime and social harm. I begin with a quick overview of some of the main topics of critical criminological inquiry, before turning to a discussion of the Trilogy as an instance of critical criminology. Next, I consider the counterfactual value of the Trilogy, i.e., the extent to which it provides knowledge of reality by means of exploring alternatives to that reality. I then move on to the phenomenological value of the Trilogy, i.e., how it provides knowledge of the lived experience of perpetrating social harm.

\footnotetext{
1 Shortly after the publication of Frauley's (2010) work on the criminological imagination, Young (2011) published The Criminological Imagination, in which he developed Mills' thesis for the purpose of bridging the gap between abstracted empiricism and grand theory in criminology.
} 


\section{What is Critical Criminology?}

Critical criminology has provided an explicit and diverse challenge to mainstream criminology for at least the last five decades. While critical criminology is a broad umbrella and while critical criminologists address a wide range of topics, Pamela Ugwudike (2015) emphasizes five subjects of study and Avi Brisman (2019b) identifies four: white-collar crime, corporate crime, state crime, racial inequality, and penal injustice for the former; and class oppression, neocolonialism, racism, and sexism for the latter. The most obvious characteristic shared by all these concepts is that they are clearly social harms irrespective of their legal status.

Edwin Sutherland (1949) produced the first study of white-collar crime, which included both crimes committed within and by businesses. Critical criminologists are often interested in white-collar crimes committed by individuals of high socioeconomic status, for example, large-scale frauds by directors rather than petty theft by employees. Corporate crime, which contains overlapping dimensions with white-collar crime, is crime committed by corporations against their employees, other businesses, or society in general (Slapper and Tombs 1999). Corporate crime has great potential for social harm because of the vast financial resources and global reach of corporations, as well their potential to influence legal authorities and governments. State crime, in turn, refers to crime and social harm committed by a government against individuals within its borders (including, but not limited to, its citizens), outside of its borders, and against other states (Green and Ward 2004). The category includes crimes against humanity, genocide, human rights abuses, violations of international law, and war crimes. White-collar crime, corporate crime, and state crime are often grouped together as crimes of the powerful (Pearce 1976; Barak 2015).

A useful way of conceiving of critical criminology is that the tradition focuses on crimes of the powerful, as noted above, social inequality, and penal injustice. These three fields should not be regarded as separate-for example, social inequality and penal injustice are standardly established and maintained by the powerful—but as indicative of typical critical criminological subject matter. Critical criminology focuses on crimes of powerful, social inequality, and penal injustice, rather than crime as defined by law, because many social harms are legal and thus go unpunished, and that arguably, many of such social harms cause more injury, violence, and death than those acts or omissions proscribed by law and referred to as "crimes."

I take one of the aims of the critical criminological project to be the reduction of social harm, which is achieved by employing theoretical and empirical investigation and verification to direct or inform public policy and evidence-based practice (Matthews 2014). One can conceptualize the chain of causation from criminology to social harm reduction proceeds as follows: criminological inquiry identifies the cause or causes of a particular social harm; the findings of the research are translated into a policy for one or more government or private agencies with the aim of reducing or removing the causal factor or factors; and the policy is put into practice resulting in the reduction of certain types of social harm or of the commission of various social harms by certain categories of offender (Agnew 2011; Garland 2001; Sutherland 1947). The key factor that links criminological research to crime or social harm reduction is the explanation of the cause of the social harm. In the remainder of this article, I demonstrate how Ellroy's Trilogy constitutes a critical criminological enterprise, i.e., the ways in which it provides an explanation of the causes of crimes of the powerful, with a particular emphasis on racial inequality, in America in the 1960s. 


\section{Ellroy's Critical Criminology}

As of July 2019, Ellroy has published twenty-one books, all on the subject of crime in the USA. His oeuvre can be divided into four distinct parts: his early fiction (six novels published from 1981 to 1986); his short work (three collections of short stories and journalism and one photographic essay published from 1994 to 2015); his autobiographies (one published in 1996 and the second in 2010); and his mature fiction (nine novels published from 1987 to 2019). Ellroy's mature fiction consists of two quartetsthe First L.A. Quartet (Ellroy 1987, 1988, 1990, 1992) and the Second L.A. Quartet (Ellroy 2014, 2019), which has yet to be completed-and a trilogy, the Underworld USA Trilogy (Ellroy 1995, 2001, 2009).

Ellroy, who lives in Los Angeles, became a public figure after the release of Curtis Hanson's L.A. Confidential (1997), a successful Hollywood film based on the third novel of the First L.A. Quartet. My interest here is restricted to the Trilogy, which consists of American Tabloid (Ellroy 1995), The Cold Six Thousand (Ellroy 2001), and Blood's a Rover (Ellroy 2009). Ellroy frames his concern with crimes of the powerful in terms of demythologizing an era of US history that is often regarded with nostalgia-as a decade of counterculture, liberation, and progress. He (Ellroy 1995: 5) states his intention in a direct address to readers, in his own voice, in an untitled prologue at the beginning of American Tabloid (and thus the whole Trilogy):

It's time to demythologise an era and build a new myth from the gutter to the stars. It's time to embrace bad men and the price they paid to secretly define their time. Here's to them.

That era begins shortly before Fulgencio Batista's flight from Cuba in the first few hours of 1959, ends shortly before the Watergate scandal in the middle of 1972, and includes numerous significant historical events, such as: the Bay of Pigs Invasion (April 1961), Operation Mongoose (from November 1961-aimed at removing communists from power in Cuba), the assassination of President John F. Kennedy (JFK) (November 1963), the escalation of America's involvement in Vietnam (March 1965), the assassination of the Reverend Doctor Martin Luther King, Jr. (MLK) (April 1968), the assassination of Robert F. Kennedy (RFK) (June 1968), the exposure of the Federal Bureau of Investigation's (FBI) COINTELPRO (March 1971), and the death of J. Edgar Hoover, the first director of the FBI (May 1972). Ellroy achieves his demythologizing by creating an alternative history in which these events are represented as crimes of the powerful and in which the real and the imagined are deliberately conflated. This history involves the disclosure of the origin and cause of social harms committed by individuals and agencies of the American government, as well as by powerful figures, such as Howard Hughes, James Riddle Hoffa, Sam Giancana, Carlos Marcello, and Santo Trafficante Jr (the last three held leadership positions in the Mafia). The Tril$o g y$ is a self-conscious critical criminological enterprise, exploring, examining, and explaining the causes of crimes of the powerful, with a particular emphasis on racial inequality. The accounts provided by Ellroy could be appropriated as part of policies or practices to reduce social harm in a similar manner to those derived from non-fictional narratives. As I will describe below, the critical criminological value of the Trilogy is in virtue of the combination of its counterfactual value and phenomenological value. 


\section{Counterfactual Value in Ellroy's Trilogy}

The term counterfactual is used in both philosophy and psychology, most often employed in the context of possible worlds, in the former, and possible alternatives to life events, in the latter. David Lewis (1973) produced the first comprehensive philosophical analysis of counterfactuals, which he conceived as propositions that express conditionals that are contrary to fact.

A conditional is a statement that takes the form of If...,Then.... An example of a conditional that is contrary to fact would be: If JFK had not withdrawn American support for the Bay of Pigs Invasion in 1961, then Fidel Castro would have been deposed as Prime Minister of Cuba. The conditional is contrary to fact because JFK did withdraw American support for the invasion and Castro was not deposed. Lewis (1986) understood counterfactuals in terms of possible worlds, such that there is an imaginable, different world in which (in contrast to our world) Castro was not premier of Cuba after 1961.

In psychology, Daniel Kahneman and AmosTversky (1982) discussed counterfactuals as assessments, fantasies, and judgments that took alternatives to reality as their subject. Drawing on Lewis (1973), Kahneman and Dale Miller (1986) explored counterfactual thinking in terms of knowledge of categories, the interpretation of experience, and the role of affect. For Kahneman, "a counterfactual" can be defined as a circumstance that has not happened, but might, could, or would happen if conditions differed from those actually existing.

There is an obvious sense in which counterfactual thinking is essentially fictional, extrapolating from reality to an alternative to reality by recourse to the imagination. Daniel Dohrn (2009) also draws on the work of Lewis (1983), using an example of Lewis' to demonstrate the relationship between fiction and reality exemplified in the counterfactual. Lewis (1983) asks whether a beggar could be dignified and suggests that fiction could provide proof that begging and dignity were not mutually exclusive. Dohrn (2009: 40) claims:

Lewis's example shows how literature may expand everyday capacities of counterfactual thinking. We cannot be sure how far the characteristics of being a beggar and of being dignified are metaphysically compatible. By imaginatively elaborating concrete characteristics of such a beggar in a counterfactual paradigm scenario, an author may sharpen our counterfactual intuitions.

Frauley (2010: 3), in turn, does not use counterfactual, but the concept is implicit in his characterization of fictional realities as an analytic tool in terms of "a disciplined imagination." The disciplined imagination is one of the means by which knowledge is acquired from fiction, linking text to reality by the combination of linguistic structure, the analytic language of criminology, the practices of reading, and the extent to which fiction is characterized by truth as well as invention. The counterfactual value of a representation is the extent to which that representation provides knowledge of reality by means of exploring alternatives to that reality.

The plots of Ellroy's mature fiction are notoriously complex. They are labyrinthine in that an end point, usually an unsolved murder, is always established at the outset, but the solution to the mystery is reached by such a tortuous route that the inaugural investigation often fades into the background for large stretches of the narrative. In order to facilitate this intricacy and manifoldness, the books are all lengthy, ranging from just under four hundred pages in the first book of the First Quartet (Ellroy 1987) to just under eight hundred pages in the first book of the Second Quartet (Ellroy 2014). With the exception of two books (Ellroy 
1987, 1992), which are narrated in the first person, the novels have multiple protagonists (two to five, most often three), employ a limited third-person narration that is fixed firmly on the point of view of the characters, and switch between or among the characters from chapter to chapter. The use of multiple protagonists contributes to the complexity by creating subplots within the overall plot that are, to use one of Ellroy's favorite words, at best "tangential" (e.g., Ellroy 1995: 139), but in which there is always, to use another of his preferred words, "convergence" (e.g., Ellroy 2001: 348) at the conclusion. One of the differences between the First L.A. Quartet and the Trilogy is the greater complexity of the latter in that all three books explicitly tell one story, albeit a story that stretches from 1958 to 2009 and follows the careers of eight protagonists. American Tabloid begins just under 6 weeks before Batista's flight from Cuba to the Dominican Republic, ends a few minutes before the assassination of JFK, and introduces Pete Bondurant, Kemper Boyd, and Ward J. Littell. Bondurant and Littell are joined by Wayne Tedrow, Jr., in The Cold Six Thousand, which begins a few minutes after the assassination of JFK and ends 3 days after the assassination of RFK. In Blood's a Rover, the main plotline begins a week after The Cold Six Thousand and ends 2 days after Hoover's death. Wayne Tedrow, Jr., is joined by Don Crutchfield and Dwight Holly. In part four (of seven) of this narrative, Scotty Bennett replaces Wayne Tedrow, Jr., as a point of view character and, in part seven, Joan Klein replaces Holly.

The notion of the Trilogy as a single story is made clear in the final section of Blood's a Rover. The novel is divided into four sections: Then (prelude, February 1964); Now (a prologue subsequently revealed to be written in 2009); Then (June 1968 to May 1972, which is divided into the seven parts noted above); and Now (epilogue, 2009). The short prologue in Now is less about the intent of the Trilogy (in the manner of Ellroy addressing his audience at the beginning of American Tabloid) and more about the verification of details and the erosion of the distinction between fact and fiction, i.e., establishing the alternative history as history rather than story. The first-person narrator (who will be revealed as Crutchfield in the epilogue) describes what is to follow:

Scripture-pure veracity and scandal-rag content. That conjunction gives it its sizzle.

You carry the seed of belief within you already. You recall the time this narrative captures and the sense of conspiracy. I am here to tell you that it is all true and not at all what you think. (Ellroy 2009: 9).

In the two-page epilogue, Crutchfield reflects on the research and writing of the third book in the Trilogy, as well as the Trilogy in its entirety. In fact, in chapter one hundred and twenty-seven (of one hundred and thirty-one), two of the main characters-Joan Klein and Karen Sifakis-discuss making Crutchfield their literary executor, giving him: "“All our files, diaries, memoranda. Everything we've put together"' (Ellroy 2009: 626). The purpose of the epilogue, thus, is threefold: to describe the creation of the archive upon which the Trilogy is based; to provide a brief summary of the lives of the surviving characters 37 years on; and to reaffirm the pivotal role of Klein in Blood's a Rover, in particular, and in the Trilogy, more generally. In this sense, Crutchfield is what Wayne Booth (1961) refers to as the "implied author" of the Trilogy, as distinguished from the "real author" (Ellroy) and the narrator or narrators (of which there are none in the Trilogy). Writing of his (implied) authorship, Crutchfield states: "Forty thousand new file pages buttress my recall. I burned all of my original paper. I built paper all over again, so I might tell you this story" (Ellroy 2009: 639).

Crutchfield's epilogue at the end of the Trilogy is the counterpart to Ellroy's prologue at the beginning of the Trilogy. What is particularly interesting in the long transition from real to implied author, from prologue to epilogue, is that after just under two thousand 
pages focusing on the lives of homophobic, racist, sexist, white men working for the government either directly or indirectly, the lynchpin of Blood's a Rover (and the whole trilogy) is Klein, a Jewish-American communist revolutionary who spends most of her life fighting fascism in its various guises both within America and internationally. Crutchfield concludes his epilogue with a reminder of her significance: "Here is my gift in lieu of a reunion-my lost mother, my lost child and Red Goddess Joan" (Ellroy 2009: 640). It is no accident that the last word of the Trilogy is Joan. Klein is a symbol of resistance to oppression, the uncompromising drive for truth, and redemption for the three amoral men (and their three predecessors) whose lives she changes in Blood's a Rover. The presence and significance of Klein similarly prevents the Trilogy from reveling in the hate and violence of its protagonists-from making its readers complicit in the voyeurism that afflicts so many of Ellroy's characters (most notably Wayne Tedrow, Jr., and Crutchfield in the Trilogy).

In the Trilogy, Ellroy presents his readers with an alternative history of America in the 1960s - one that is completely critical of the US government and of those exerting power behind it, but nonetheless all based on contested fact. In American Tabloid, he replaces the myth of the Camelot Era of JFK's administration with the myth of Bondurant, Boyd, and Littell, carving out the will of Hughes in Los Angeles, Cuban exiles in Miami, and the Mafia in Chicago (Hersh 1997; Tate and Johnson 2018). In the remainder of the Trilogy, the popular image of the 1960s as a decade of civil rights, gay liberation, and second-wave feminism is replaced by the representation of cruelty, repression, and unaccountability. Wayne Tedrow, Jr., Crutchfield, and Holly pick up where their predecessors left off as Ellroy, in The Cold Six Thousand, turns his attention to Operation Mongoose, the state-sanctioned terrorism against Cuba that began in November 1961 and is believed to have been maintained unofficially throughout the 1960s and 1970s (Chomsky 2003; US Department of State 1962; Wyden 1979), and, in Blood's a Rover, to COINTELPRO, the FBI's surveillance and harassment of civil rights and black power groups (among others) from 1956 to 1971 (Medsger 2014; Pepper 2003; US Senate 1976). As a result of the combination of so many real people and events with an oversufficiency of subplots that reproduces reality, Ellroy's history is presented as if it is at least partly true-not in every single detail (the protagonists are all fictional), but as an authentic depiction of what was really happening in America in the 1960s.

One of the fascinating features of the Trilogy is that even the apparently most farfetched events described by Ellroy have a basis in fact, such as the almost absolute power wielded by Hoover in Blood's a Rover and the Central Intelligence Agency's (CIA) plot to traffic heroin from Vietnam to the black suburbs of Las Vegas in The Cold Six Thousand. Hoover was head of the FBI (and its predecessor, the Bureau of Investigation) for an incredible 48 years, serving eight presidents; he was accused frequently of using the vast intelligence resources at his disposal for the purposes of blackmail (Summers 1993; Weiner 2012). Whether or not he was as pathologically racist as Ellroy represents, he had an extreme hatred of communism and regarded many of the progressive movements in the USA, including civil rights, as communist-inspired (Gentry 1991). Hoover's obsession with communism was balanced by his lack of concern with organized crime and he famously claimed that the Mafia did not exist (Gentry 1991). Ellroy's summary, from Holly's point of view, seems very accurate indeed: "Mr. Hoover had no beef with organized crime. That was strictly Bobby K.'s bête noire and downfall. Mr. Hoover hated Commies, jigs and lefty gadflies" (Ellroy 2009: 61).

The first allegations of CIA involvement in narcotics importation to the USA were made in 1996, by journalist Gary Webb, who reported on links between the CIA, the Contras 
(anti-communists in Nicaragua), and the crack cocaine epidemic in South Los Angeles in the 1980s (Webb 1998). Webb (1998) subsequently published his investigation as a book, Dark Alliance: The CIA, the Contras, and the Crack Cocaine Epidemic. Details were denied and confirmed by the different parties involved, but the claims and counterclaims were, rather conveniently, brought to an end with Webb's suicide in 2004 (Grim et al. 2014). ${ }^{2}$

Counterfactual knowledge typically provides knowledge of reality by means of the exploration of alternatives to that reality, but the Trilogy accomplishes much more than this. Ellroy suggests-both in his direct address to readers and through Crutchfield as his implied author - that if the US, in the 1960s, was not exactly as represented in his fiction, the fiction is significantly closer to the reality than the mythologized version of the era. While Bondurant, Crutchfield and Tedrow, Jr., are fictional, the centers of power for whom they work — especially Hoover, the Mafia, and the CIA — are (or were) not and the implication is that the counterfactual knowledge conveyed by Ellroy provides as much knowledge of an alternative America as it does of a probable America. The counterfactual value of the Trilogy alone is, however, insufficient to constitute a critical criminology: because the counterfactual knowledge conveyed describes numerous crimes of the powerful, it does not explore their causes in any detail. Nevertheless, the detailed explanation of the causes of social harm is provided in the phenomenological knowledge conveyed in the Trilogy and in the lived experience of the perpetrators of social harm. And it is the combination of the counterfactual values and phenomenological values of the Trilogy that constitutes Ellroy's critical criminology.

\section{Phenomenological Value in Ellroy's Trilogy}

Dorothy Walsh (1969) is credited with identifying three distinct types of knowledge that representations can provide: knowledge-that (information about something — such and such is so); knowledge-how (instruction as to how to perform some act); and knowledge-what (descriptions of what something is like). The realization of what a particular lived experience is like is standardly referred to as phenomenological knowledge.

John Gibson (2008: 582-583) explains how representations provide phenomenological knowledge, using a novel and a film as examples:

Drawing solely on my own experiences and my preferred books of theory, I will acquire no significant knowledge of what it is like to be a victim of systematic racial oppression or an immigrant struggling to make his way to an unwelcoming country.

But I can read Ralph Ellison's Invisible Man or watch Elia Kazan's America, America and in so doing acquaint myself with a region of human experience that would otherwise remain unknown to me.

In order to acquire phenomenological knowledge, it is necessary to not only experience an/the representation, but to accept the author or director's invitation to adopt an approved set of cognitive, emotional, and evaluative responses to the representation. For example, if one fails to accept Ellison's (1952) invitation to regard the anonymous narrator of Invisible

\footnotetext{
${ }^{2}$ Marlon James (2014), who employs a similar blend of fact and fiction in A Brief History of Seven Killings, also explores the relationship between the CIA and the crack cocaine epidemic in New York during the same period.
} 
Man as a sympathetic character, then one will not realize what it is like to be a victim of systematic racial oppression. In a case such as Martin Amis' (2014) The Zone of Interest, readers may reject the explanation of protagonist Angelus Thomsen's active participation in the National Socialist genocide by means of the vice of akrasia (lack of self-control). Readers who do adopt Amis' perspective on Thomsen do not have to become temporary or permanent apologists for National Socialism, but they must temporarily set aside their moral horror if they are to understand the lived experience of a participant in genocide as represented in the novel.

Criminological interest in lived experience is widespread, extending from the victims of crime or social harm to criminal justice workers and offenders (Presser 2009). My focus here is on the lived experience of the perpetrators of social harm in light of the more direct link between their experiences and the critical criminological project. Phenomenological knowledge of the perpetrator of social harm is more likely to explain the cause of that social harm than phenomenological knowledge of the victims or criminal justice workers involved. For my purposes, then, the phenomenological value of a representation is the extent to which that representation provides knowledge of the lived experience of perpetrating social harm. While the practice of fiction typically involves less correspondence with reality and more so-called fabrication, there is no prima facie reason that a particular fictional representation should not be as valuable to criminologists as some non-fictional representations, given that fictional representations can provide phenomenological knowledge that is not available to non-fictional representations.

Joshua Page and Philip Goodman (2018) discuss the difficulties of practicing what Loïc Wacquant (2005) calls carnal sociology in the context of researching crime and punishment. They note the problems of access and ethics with regard to experiencing or witnessing the embodied nature of behavior in the environments in which criminologists are interested. In the case with which Page and Goodman are concerned-the embodiment of prisonization - there are also legal considerations, and they argue that Edward Bunker's (1977, 1981) fictionalized autobiographies can be employed to overcome these impediments to criminological analysis. The ability of fictional representations to provide phenomenological knowledge that is not available to non-fictional representations for access, ethical, or legal reasons is an important component of their criminological value.

The protagonists of Ellroy's mature fiction are almost exclusively white male law enforcement officials (or former law enforcement officials) who evince the prejudices of their times: homophobia, racism, and sexism ranging from the casual to the pathological. They are always alcohol- and drug-fueled workaholics driven by inner demons; frequently obsessed with particular women (absent mothers, murder victims, or fantasy partners); usually complicit in rather than critical of corruption; often universityeducated; sometimes ambivalent about their prejudices; and occasionally, themselves, homosexual. In the most-repeated tripartite structure (Ellroy 1988, 1990, 1995, 2001), there are two obvious alpha males, one hyper-masculine and the other ruthlessly ambitious, and an apparently beta male who later turns the tables on the other two in a victory of brains over brawn. ${ }^{3}$ Taken as a whole, the Trilogy is more complex, employing Tedrow, Jr., to provide the link between the assassination of JFK in American Tabloid, Operation Mongoose in The Cold Six Thousand, and COINTELPRO in Blood's a Rover.

\footnotetext{
${ }^{3}$ Despite initial appearances to the contrary, Ellroy is highly critical of hegemonic masculinity and the toxic practices with which it is associated. The critique is most evident in the positioning of Klein, but also in the roles of Barb, Janice Lukens (Tedrow, Jr.'s stepmother), and Mary Beth in the Trilogy.
} 
Bondurant and Holly are the hyper-masculine alphas, Boyd the ruthless alpha, and Littell and Crutchfield betas-turned-alphas (Bennett and Klein appear too late in Blood's a Rover to alter this overall structure.) My demonstration of the way in which Ellroy employs the lived experience of his protagonists to explain the causes of social harm involves an examination of his representation of the hyper-masculine Bondurant, of Tedrow, Jr., as the thread that binds the Trilogy together, and of the beta-turned-alpha Crutchfield.

Bondurant is perhaps the most interesting protagonist in the Trilogy because, unlike the other hyper-masculine alpha male (Holly), he is not overly troubled by his conscience and never switches sides from the powerful to the oppressed. As such, he is probably the most reprehensible, but is not portrayed as completely despicable. In drawing attention to Bondurant's few virtues, as well as his many vices, Ellroy reveals that the motivation behind complicity in crimes of the powerful is not necessarily selfish. Big Pete Bondurant is a physically imposing man, a six-foot-five, two hundred and thirty pound French-Canadian with a fifty-two inch chest. He is thirty-eight when the Trilogy begins, a highly decorated World War II veteran, a former Los Angeles Sheriff's Department deputy, and a licensed private investigator. Like many of Ellroy's protagonists, Bondurant guards an appalling secret: while completing a contract killing for Los Angeles gangster, Mickey Cohen, in 1949, he accidentally shot his own brother dead. Bondurant is pathologically racist and shares the casual homophobia and sexism of the era. On the recommendation of Boyd, he is recruited to the CIA in 1959 to run the Blessington camp of Cuban exiles preparing for the Bay of Pigs Invasion, as "an impressive white man" to keep control of the Cubans and to instill fear into the local Ku Klux Klan (Ellroy 1995: 173). Bondurant takes part in the Bay of Pigs as an observer and in Operation Mongoose as a combatant. In 1962, he meets Barbara Jane Linscott ("Barb"), an entertainer at the Reef Club in Los Angeles. His initial interest is in recruiting her to spy on JFK, but after sleeping with her, Bondurant soon falls in love, and they marry just before the assassination. American Tabloid closes with Bondurant knowing that the assassination is about to take place and fearing that Barb will leave him when she realizes his involvement: "The roar did a long slow fade. He braced himself for this big fucking scream" (Ellroy 1995: 585).

This particular scene is crucial to understanding Bondurant because it draws attention to his two main virtues. The first is loyalty. To the causes to which he chooses to dedicate himself - most notably, the overthrow of Castro- he is both unfailingly loyal and entirely selfless. Like many of the Cuban exiles themselves, he feels betrayed by JFK's withdrawal of support for the invasion when it is needed most. The betrayal is his primary motivation for supporting Littell's plan to kill JFK in American Tabloid, and he agrees to traffic heroin from Vietnam to Las Vegas in order to fund Operation Mongoose in The Cold Six Thousand. When Bondurant discovers that the profits from the heroin have been funneled elsewhere, he kills his CIA handler. In addition to his loyalty to the Cuban cause, Bondurant is almost unique as an Ellroy protagonist in remaining faithful to Barb, from the moment he meets her until the two of them retire to Sparta in Wisconsin.

Bondurant's second virtue is his kindness, which he demonstrates by taking Tedrow, Jr., under his wing and saving Littell's life shortly before the RFK assassination (both at personal cost to himself). What is important to note is that Bondurant is not redeemed by his love for Barb-he retains a sociopathic disregard for those outside of his immediate sphere of concern-but he does make a final and very late transition from hate to love. Bondurant is the only protagonist of the Trilogy allowed to recede into the anonymity he desires, which constitutes something of an endorsement from Ellroy, even if that validation does not reach the heights of redemption. The criminological insight provided by the 
exploration of Bondurant's character is the way in which his fanaticism (a vice) and loyalty (a virtue) combine to motivate the perpetration of social harm committed on behalf of the Cuban exiles, CIA, and organized crime.

Tedrow, Jr., is Ellroy's most obviously Freudian character, the product of an overbearing father and an absent mother, obsessed with his stepmother, and torn between extremes: he both embraces and resists his father's white supremacism and is both redeemed and condemned by his relationship with Klein. The Cold Six Thousand opens with Tedrow, Jr., a 29-year-old sergeant in the Las Vegas Police Department (LVPD), arriving in Dallas with the intention of killing Wendell Durfee, a black pimp wanted by the Casino Operators Council, for a bounty of six thousand dollars. Tedrow, Jr., is conflicted about his mission, undertaken with the blessing of the LVPD, and brings it to a close by killing his partner in the Dallas Police Department and allowing Durfee to escape. Tedrow, Jr., returns to Las Vegas, where his antagonism toward his father and disgust for attempts to smear the reputation of MLK reveal his racism as reluctant at best. Meanwhile, Durfee thinks Tedrow, Jr., is still a threat, returns to Las Vegas to kill him, and rapes and murders his wife. Wracked with guilt, Tedrow, Jr., murders three of Durfee's associates, is dismissed from the LVPD, and makes a commitment to anti-black racism. Tedrow, Jr., has both a military background and a chemistry degree and is recruited by Bondurant to run the laboratory where the heroin destined for Las Vegas will be made. Tedrow, Jr., divides his time between cooking heroin in Vietnam and searching for Durfee in the USA until Holly (who is working for Hoover) provides him with Durfee's whereabouts. Tedrow, Jr., kills him and is then coerced into organizing the murder of King (with Hoover's consent). The Cold Six Thousand concludes with Tedrow, Jr., helping his stepmother kill his violently abusive father in the beginning of the slow process of redemption that will continue with Mary Beth Hazzard in Blood's a Rover and conclude with Klein.

When Tedrow, Jr., finds out that the police are going to frame Pappy Dawkins, a black burglar, for the murder of his father, he seeks to warn Dawkins, but kills him and his associate, the Reverend Cedric D. Hazzard, in self-defense. Motivated by guilt for the deaths of King, Dawkins, and Hazzard, he approaches Hazzard's widow, Mary Beth, and offers to help find her son, who has been missing for 5 years. He has an affair with Mary Beth, confessing several of his racially motivated crimes to her, and begins donating profits from Mafia operations to black militants in America and communists in the Dominican Republic. After helping slaves escape in the Dominican Republic, he returns to find that Mary Beth has been told about his role in the assassination of MLK. When she leaves him, he steals close to one and a half million dollars from his Mafia employers, delivers the money to Klein in the Dominican Republic, and walks across the border to Haiti. When death finds him, he does not resist:

An alleyway appeared. A breeze carried him down it. Leaves stirred and sent rainbows twirling. Three men stepped out of a moonbeam. They wore cross-drawn scab-

bards. They had bird wings where their right arms used to be.

Wayne said, "Peace."

They pulled their machetes and cut him dead right there. (Ellroy 2009: 421).

From a critical criminological point of view, the exploration of Tedrow, Jr.'s character is revealing in demonstrating both the similarity between apparently opposed forms of extremism and the significance of the emotions in the perpetration of social harm. His white supremacism and anti-imperialism are ultimately motivated by love, first for his wife and then Mary Beth. Ellroy suggests that Tedrow, Jr.'s swing between extremesfrom conspiring to murder MLK to sacrificing his life for Klein's revolution-is not as 
paradoxical as it initially seems because both acts are symptomatic of his desire to create meaning in his life by committing himself to a cause. The relationship between the extremes and emotions is that the latter determines the direction of the former.

Crutchfield is, to date, the paradigm of Ellroy's stable of beta males becoming alpha-men who are scared, shy, or subdued at the beginning of a novel but turn the tables on their alpha male oppressors to take charge of the plot. He is a 23-year-old wheelman when Blood's a Rover begins, an unlicensed and unskilled private investigator: "They were low-rent and indigenously fucked-up. They perched in the lot. They waited for work from skank private eyes and divorce lawyers. They tailed cheating spouses, kicked in doors and took photos of the fools balling" (Ellroy 2009: 23-24).

Crutchfield is unusually enthusiastic about such a distasteful job because it provides him with ample opportunity for indulging his voyeurism, which is of paraphiliac proportions. His sexual gratification comes courtesy of watching women through their windows, particularly those of his mother's age, and occasionally breaking into steal trophies. Like Tedrow, Jr., Crutchfield is the product of an absent mother, who abandoned him when he was 10 years old, and all-too-present father, who is a homeless gambling addict. As such, Crutchfield is attracted to male role models, first Bennett (a sergeant in the Los Angeles Police Department) and then Jean Philippe Mesplède (the French mercenary who shot JFK in American Tabloid). Like Ellroy's other protagonists, he suffers from the prejudices of his era, but with little conviction, easily assimilating the views of the more dominant men and women into whose orbit he is drawn. Crutchfield's attraction to older women sets the scene for what will become a fixation with Klein, whom he first sees while working surveillance. On the same night, he discovers the body of a mutilated murder victim, which appears to be linked to the armored car heist with which Blood's a Rover opens (the prelude, set in 1964).

Crutchfield's peripheral position with respect to all of the other protagonists-Bennett, Holly, Klein and Tedrow, Jr.--places him ideally with respect to uncovering what, for the reader, is the plot of the novel: the links between the armored car heist, the mutilated victim, and Klein's secret life. Crutchfield describes this broader view of events as: "Confluence. Clyde Duber's word. It's who you know and who you blow and how you're all linked" (Ellroy 2009: 152 (emphasis in original)). After 18 months of working for the Mafia in the Dominican Republic and with Mesplède on Operation Mongoose, Crutchfield returns to his lowly life as a wheelman, free to investigate the three mysteries with which he has become obsessed. Klein takes him as a lover, tells him the story of her revolutionary life, and becomes pregnant by him. Unlike the beta males of Ellroy's other novels, Crutchfield's victory over the alphas is posthumous. He, alone, has the most meaningful relationship with Joan (fathering her child), and he, alone, is left to tell the story of Bennett, Bondurant, Boyd, Holly, Littell, and Tedrow, Jr.- their stories are subsumed under his story and his history is the story of the Trilogy in his role as its implied author.

The critical criminological value of the exploration of Crutchfield's character is in the way in which it draws attention to the structural causes of social harm, the influence of the power wielded by the perpetrators of crimes of the powerful (Hoover, the Mafia, the CIA) and those in their employ (Holly, Mesplède, Tedrow, Jr.), who motivate others by a compelling mix of ambition, awe, and fear. Crutchfield is also significant in that his relentless researching, record-keeping, and archiving constitute a self-reflexive commentary on the writing of the Trilogy by Ellroy-concluding the idea he begins in the prologue of American Tabloid through not only Crutchfield's epilogue, but the 
development of his personality from irresponsible perpetrator of social harm to mature critical criminological researcher.

\section{Conclusion: Critical Criminological Imagination}

In the previous sections, I demonstrated the counterfactual and phenomenological values of Ellroy's Trilogy. The counterfactual value rests with his alternative history of America, which is framed in such a way that its content is represented as probable rather than alternative-an account of the period that is more authentic than the popular history, if not entirely accurate (due to the blend of fact and fiction). The events of this alternative history are viewed through the lens of the Trilogy's eight protagonists, six of whose experiences, motivations and personalities are probed in rich detail.

This exploration is also the source of the phenomenological value of the Trilogy-the knowledge of what it is like to be a perpetrator of social harms that Ellroy conveys so effectively. In Frauley's (2010: 95) terminology, Ellroy exercises his criminological imagination by seamlessly integrating the "realm of public issues" (alternative history) with the "realm of personal troubles" (individual motivation) in the Trilogy. The combination of the public and the personal -in depth and at length - also provides a map of the structure of American social reality in the 1960s. Finally, Ellroy's emphasis on the structural causes of social harm over and above the psychological causes establishes a conceptual system in which data can be interpreted. In light of his concern with crimes of the powerful, with social harm, and with structure over agency, Ellroy's criminological imagination can be characterized as critical in orientation. This critical criminological imagination is employed to explain the causes of social harm committed by the powerful in America in the 1960s. When approached from the narrative criminological framework discussed in Introduction to this article, Ellroy's intentional and meticulous scrutiny of the crimes of the powerful is an explicitly critical criminological enterprise such that the Trilogy constitutes an instance of critical criminology - an explanation of the causes of social harm that can be applied to the reduction of social harm in practice.

If I am correct and the Trilogy does, indeed, provide counterfactual and phenomenological knowledge to the extent that that it constitutes a critical criminology, then I have also sketched an argument for the potential criminological value of fiction more generally: fiction can provide counterfactual and phenomenological knowledge and both counterfactual and phenomenological knowledge can explain the causes of crime or social harm. There is no apparent reason to restrict the criminological value of literary fiction and future research might, for example, involve a comparison of the knowledge provided by Ellroy's First L.A. Quartet with the knowledge provided by Hanson's L.A. Confidential (1997).

In putting forth this argument that Ellroy's Trilogy constitutes a kind of critical criminology, I wish to make clear that I am not suggesting that the knowledge conveyed by fictional narratives is more-or even as-valuable as the knowledge conveyed by nonfictional representations or discursive texts. Such a claim would be both obviously false and highly irresponsible. What I am proposing, however, is that some fictional narratives can provide knowledge independently of corroborative sources. In other words, that the criminological value of the Trilogy for which I have argued is not, as I previously claimed (McGregor 2018), reliant on its juxtaposition with comparative documentaries. The use of 
a combination of fictional and documentary sources may well be the most advantageous and prudent method to deploy, but it is not necessary for fictional narratives that are themselves criminological. ${ }^{4}$

Open Access This article is distributed under the terms of the Creative Commons Attribution 4.0 International License (http://creativecommons.org/licenses/by/4.0/), which permits unrestricted use, distribution, and reproduction in any medium, provided you give appropriate credit to the original author(s) and the source, provide a link to the Creative Commons license, and indicate if changes were made.

\section{References}

Agnew, R. (2011). Toward a unified criminology: Integrating assumptions about crime, people, and society. New York: New York University Press.

Amis, M. (2014). The zone of interest. London: Jonathan Cape.

Aristotle, (2004). Poetics. Trans. P. Murray \& T.S. Dorsch. In P. Murray (Ed.), Classical literary criticism (pp. 57-97). London: Penguin.

Atherton, M. C. (2013). Teaching through film: Utilizing popular criminology in the classroom. Journal on Excellence in College Teaching, 24(2), 77-99.

Barak, G. (Ed.). (2015). The Routledge international handbook of the crimes of the powerful. Abingdon: Routledge.

Booth, W. C. (1961). The rhetoric of fiction. Chicago: University of Chicago Press.

Brisman, A. (2013). Not a bedtime story: Climate change, neoliberalism and the future of the Arctic. Michigan State International Law Review, 22(1), 241-289.

Brisman, A. (2017). On narrative and green cultural criminology. International Journal for Crime, Justice and Social Democracy, 6(2), 64-77.

Brisman, A. (2019a). The fable of the three little pigs: Climate change and green cultural criminology. International Journal for Crime, Justice and Social Democracy, 8(1), 46-69.

Brisman, A. (2019b). Editor's Introduction to the Special Issue: "Crucial Critical Criminologies—Revisited and Extended". Critical Criminology: An International Journal, 27(1), 1-4.

Bunker, E. (1977). The animal factory. New York: Viking Press.

Bunker, E. (1981). Little boy blue. New York: St Martin's Griffin.

Cavender, G., \& Jurik, N. C. (2012). Justice provocateur: Jane Tennison and policing in prime suspect. Chicago: University of Illinois Press.

Chomsky, N. (2003). Hegemony or survival: America's quest for global dominance. New York: Metropolitan Books.

Confidential, L. A. (1997). Directed by Curtis Hanson. Burbank, CA: Warner Bros.

Dohrn, D. (2009). Counterfactual narrative explanation. The Journal of Aesthetics and Art Criticism, 67(1), 37-47.

Ellison, R. (1952). Invisible man. New York: Random House.

Ellroy, J. (1987/1993). The black dahlia. London: Arrow.

Ellroy, J. (1988/1990). The big nowhere. London: Arrow.

Ellroy, J. (1990/2005). L.A. Confidential. London: Arrow.

Ellroy, J. (1992/2005). White jazz. London: Arrow.

Ellroy, J. (1995). American tabloid. London: Arrow.

Ellroy, J. (2001/2010). The cold six thousand. London: Windmill.

Ellroy, J. (2009/2010). Blood's a rover. London: Windmill.

Ellroy, J. (2014/2015). Perfidia. London: Windmill.

Ellroy, J. (2019). This storm. Portsmouth: William Heinemann.

Frauley, J. (2010). Criminology, deviance, and the silver screen: The fictional reality and the criminological imagination. New York: Palgrave Macmillan.

Garland, D. (2001). The culture of control: Crime and social order in contemporary society. Oxford: Oxford University Press.

Gentry, C. (1991). J. Edgar Hoover: The man and the secrets. New York: Norton \& Company.

\footnotetext{
${ }^{4}$ I would like to thank Alana Barton and Vladimir Rizov for their invaluable assistance with this article.
} 
Gibson, J. (2008). Cognitivism and the arts. Philosophy Compass, 3(4), 573-589.

Green, P., \& Ward, T. (2004). State crime: Governments, violence and corruption. London: Pluto Press.

Grim, R., Sledge, M., \& Ferner, M. (2014). Key figures in CIA-crack cocaine scandal begin to come forward. HuffPost US. 10 October. Available at: https://www.huffingtonpost.co.uk/entry/gary-webbdark-1liance_n_5961748?guccounter=1\&guce_referrer_us=aHR0cHM6Ly93d3cuZ29vZ2x1LmNvLn VrLw\&guce_referrer_cs=EW4ghLEqh3yApoJ3K8UvVA.

Hersh, S. (1997). The dark side of camelot. London: HarperCollins Publishers.

James, M. (2014). A brief history of seven killings. London: Oneworld.

Kahneman, D., \& Miller, D. T. (1986). Norm theory: Comparing reality to its alternatives. Psychological Review, 93(2), 136-153.

Kahneman, D., \& Tversky, A. (1982). The simulation heuristic. In D. Kahneman, P. Slovic, \& A. Tversky (Eds.), Judgment under uncertainty: Heuristics and biases (pp. 201-208). New York: Cambridge University Press.

Lamarque, P., \& Olsen, S. H. (1994). Truth, fiction, and literature: A philosophical perspective. Oxford: Clarendon.

Lewis, D. (1973). Counterfactuals. Oxford: Blackwell.

Lewis, D. (1983). Truth in fiction. In Philosophical papers, (vol 1, pp. 261-280). Oxford: Oxford University Press.

Lewis, D. (1986). On the plurality of worlds. Oxford: Blackwell.

Maruna, S. (2001). Making good: How ex-convicts reform and build their lives. Washington, DC: American Psychological Association.

Matthews, R. (2014). Realist criminology. London: Palgrave Macmillan.

McGregor, R. (2016). The value of literature. London: Rowman \& Littlefield International.

McGregor, R. (2018). Narrative justice. London: Rowman \& Littlefield International.

Medsger, B. (2014). The burglary: The discovery of J. Edgar Hoover's secret FBI. New York: Knopf.

Mills, C. W. (1959). The sociological imagination. New York: Oxford University Press.

Page, J., \& Goodman, P. (2018). Creative disruption: Edward Bunker, carceral habitus, and the criminological value of fiction. Theoretical Criminology. https://doi.org/10.1177/1362480618769866.

Pearce, F. (1976). Crimes of the powerful: Marxism, crime and deviance. London: Pluto Press.

Pepper, W. F. (2003). An act of state: The execution of Martin Luther King. London: Verso.

Presser, L. (2008). Been a heavy life: Stories of violent men. Champaign, IL: University of Illinois Press.

Presser, L. (2009). The narratives of offenders. Theoretical Criminology, 13(2), 177-200.

Presser, L. (2013). Why we harm. New Brunswick, NJ: Rutgers University Press.

Presser, L. (2016). Criminology and the narrative turn. Crime, Media, Culture: An International Journal, 12(2), 137-151.

Presser, L., \& Sandberg, S. (Eds.). (2015). Narrative criminology: Understanding stories of crime. New York: New York University Press.

Presser, L. \& Sandberg, S. (2019). Narrative criminology as critical criminology. Critical Criminology: An International Journal, 27(1), 131-143.

Rafter, N. (2006). Shots in the mirror: Crime films and society (2nd ed.). New York: Oxford University Press.

Rafter, N., \& Brown, M. (2011). Criminology goes to the movies: Crime theory and popular culture. New York: New York University Press.

Ruggiero, V. (2003). Crime in literature: Sociology of deviance and fiction. London: Verso.

Sandberg, S. (2010). What can "Lies" tell us about Life? Notes towards a framework of narrative criminology. Journal of Criminal Justice Education, 21(4), 447-465.

Sandberg, S., \& Pedersen, W. (2009). Street capital: Black cannabis dealers in a white welfare state. Bristol: Policy Press.

Sandberg, S., \& Ugelvik, T. (2016). The past, present, and future of narrative criminology: A review and an invitation. Crime, Media, Culture, 12(2), 129-136.

Slapper, G., \& Tombs, S. (1999). Corporate crime. Harlow: Pearson Education Limited.

Summers, A. (1993). Official and confidential: The secret life of J. Edgar Hoover. New York: Putnam.

Sutherland, E. H. (1947). Principles of criminology (4th ed.). Philadelphia, PA: J.B. Lippincott \& Co.

Sutherland, E. H. (1949). White collar crime. New York: Holt, Rinehart \& Winston.

Tate, T., \& Johnson, B. (2018). The assassination of Robert F. Kennedy: Crime, conspiracy and cover-upA new investigation. London: Thistle.

Ugelvik, T. (2014). Power and resistance in prison: Doing time, doing freedom. London: Palgrave Macmillan.

Ugwudike, P. (2015). An introduction to critical criminology. Bristol: Policy. 
US Department of State. (1962). Foreign relations of the United States 1961-1963. Volume X: Cuba 19611962. 18 January. Washington, DC. Available at: https://www.mtholyoke.edu/acad/intrel/cuba/mongo ose.htm.

US Senate. (1976). Intelligence activities and the rights of Americans book II: Final report of the select committee to study governmental operations with respect to intelligence activities. 26 April. Washington, DC. Available at: https://www.intelligence.senate.gov/sites/default/files/94755_II.pdf.

Wacquant, L. (2005). Carnal connections: On embodiment, apprenticeship, and membership. Qualitative Sociology, 28(4), 445-474.

Walsh, D. (1969). Literature and knowledge. Middletown, CT: Wesleyan University Press.

Webb, G. (1998). Dark alliance: The CIA, the contras, and the crack cocaine explosion. New York: Seven Stories.

Weiner, T. (2012). Enemies: A history of the FBI. London: Penguin.

Wyden, P. (1979). Bay of pigs: The untold story. New York: Simon and Schuster.

Young, J. (2011). The criminological imagination. Cambridge: Polity.

Publisher's Note Springer Nature remains neutral with regard to jurisdictional claims in published maps and institutional affiliations. 